\title{
Lab-scale degradation of leather industry effluent and its reduction by Chlorella sp. SRD3 and Oscillatoria sp. SRD2: a bioremediation approach
}

\author{
S. Santhosh ${ }^{1}$ A. M. Rajalakshmi ${ }^{2} \cdot$ M. Navaneethakrishnan $^{2} \cdot$ S. Jenny Angel ${ }^{2} \cdot$ R. Dhandapani $^{2}$
}

Received: 27 September 2019 / Accepted: 2 April 2020 / Published online: 18 April 2020

(c) The Author(s) 2020

\begin{abstract}
The present study focuses on treatment of tannery effluent samples using microalgae and isolated cyanobacteria. Different concentrations of both the effluent samples were treated with the algal isolates and a highest biomass of $0.295 \mathrm{~g} / \mathrm{l}$ was attained in $50 \%$ of concentration on the 12th day in BHEL site. The biomass production in Walajapet site was found to be $0.387 \mathrm{~g} / \mathrm{l}$ in the effluent treated with 50\% of algae. The treated effluent was tested for growth and chlorophyll content was estimated, Chlorella sp. SRD3 showed higher chlorophyll content. The 50\% treatment was processed at large-scale treatment in lab and biomass yield of $0.65 \pm 0.04 \mathrm{~g} / \mathrm{l}$ was achieved in BHEL site and $0.49 \pm 0.028 \mathrm{~g} / \mathrm{l}$ in Walajapet site. The treatment led to higher reduction rates in BOD and COD levels in treated effluents. The BOD in effluent from BHEL site was reduced to $83.41 \%$ and that from Walajapet site showed $87.46 \%$ reduction, whereas the COD values also showed $78 \%$ reduction. Based on the results, effluent sample serves as a medium for growth and bioremediation of tannery effluents by microalga, Chlorella sp. SRD3 revealed promising results which may prove efficient in the near future.
\end{abstract}

Keywords Chlorella sp. · Phycoremediation · Tannery $\cdot$ Fluorescent $\cdot$ Chlorophyll

\section{Introduction}

Microalgae serve as a better source for wastewater treatment as they are capable in utilizing the minerals by converting them to biomass (Amenorfenyo et al. 2019). Nutrients were consumed within the microbes for growth leading to a reduction in the minerals and the BOD, COD levels. Wastewater is considered to be discharged from industrial and domestic effluents consisting toxic suspended solid particles (Sara et al. 2012). When these toxic particles are released into waste systems, it leads to aquatic threat in the environment (Abdel-Raouf et al. 2012). The treatment by microalgae leads to nutrients removal, heavy metal ions and pathogens. It leads to reduction in BOD levels and production of oxygen

R. Dhandapani

danpaniramurthy@gmail.com

1 Applied Microbiology Laboratory, Department of Microbiology, Periyar University,

Salem, Tamilnadu 636011, India

2 Fermentation Technology Laboratory, Department of Microbiology, Periyar University, Salem, Tamilnadu 636011, India by photosynthetic reaction in a variety of toxicant removal and biogas production techniques. The nutrients and water uptake by microalgae does not happen in a particular system as they are dependent on larger surface area for utilization of toxic minerals. Heavy metal toxicity in the environment is a major concern, because it affects the natural flora and fauna; hence the wastewater and sewage should be treated (Adefila et al. 2010). In the upcoming years, heavy metals are becoming a sole factor in polluting the environment (Sayin et al. 2011). Toxic metal pollutants such as chromium, lead and cadmium are abundantly present in the leather industry wastes (Karthi and Meenakshi 2014; Balaji et al. 2016). The wastewater treatment is a cost-intensive physicochemical means and cannot be employed in industries of most of the emergent countries. Hence, the importance of bio-based treatment systems is spreading all across the world and is becoming an efficient, cost effective system that attracted among many people (Vijayakumar and Manoharan 2012). As per the previous reports, cyanobacteria Oscillatoria (Vijayakumar et al. 2005), Spirulina platensis (Boominathan and Manoharan 2008) and Westiellopsis (Vijayakumar et al. 2005) are successfully used for the heavy metals removal from wastewater Wang et al. (2010) revealed in their study 
that algae can ingest the organic pollutants into cell constituents thereby reduction of pollutants an eco-friendly means. Leather industries exist from a longer time and environmental pollution has become a major problem in the recent decade (Dhal et al. 2013). The present study involves the algae-based treatment of tannery effluent collected from two sites namely BHEL and Walajapet area in Tamilnadu, and treating them with fresh-water microalgae and cyanobacteria. Treatment of tannery effluent with these isolates showed that Chlorella sp. SRD3 was more efficient in degrading the toxic metals present. The growth was monitored in terms of biomass and chlorophyll content. While the physiochemical parameters were analyzed both before and after treatment to observe the extent of degradation. Carbohydrate and protein content was tested during the large-scale treatment in the lab conditions. The metals analyzed in the effluents had Chromium and magnesium content present, that were degraded from 60 to $80 \%$ in both the sites.

\section{Materials and methods}

\section{Culture collection}

The microalgae Chlorella sp. SRD3 (NCBI Gene bank, accession number-MH879820) were obtained from department of microbiology and cyanobacterial strain was isolated from Mettur dam, Salem, Tamilnadu. The collected microalgae species were identified based on the monograph of Desikachary (1959); molecular identification of the cyanobacteria is done by $16 \mathrm{~s}$ rRNA sequencing. The cyanobacterium was grown in $\mathrm{BG} 11$ medium and microalga in bold basal medium (BBM) kept at $28{ }^{\circ} \mathrm{C}$ for $16 \mathrm{~h}$ light: $8 \mathrm{~h}$ dark conditions under fluorescent light. Both the isolates were observed morphologically under compound microscope at $400 \times$ magnification.

\section{Collection of tannery effluent}

The raw leather industry effluents were collected from two different places in Vellore district in Tamil Nadu namely BHEL (Bharat Heavy Electronics Limited) $\left(12.9321^{\circ} \mathrm{N}\right.$, $\left.79.3335^{\circ} \mathrm{E}\right)$, and Walajapet $\left(12.9250^{\circ} \mathrm{N}, 79.3669^{\circ} \mathrm{E}\right)$.

\section{Morphological characterization of cyanobacteria}

The genomic DNA was extracted from isolated cyanobacteria by CTAB method followed by Singh et al. (2011). The DNA was amplified by polymerase chain reaction using forward and reverse primers CYAN738F 5'ATACCCCWG TAGTCCTAGC3' and CYAN1281R-5'GCAATTACTAGC GATTCCTCC3', respectively. The phylogenetic tree was constructed using the neighbor-joining method (Saitou and Nei 1987) as implemented using MEGA 6.06 software.

\section{Screening of different effluent concentration}

The collected effluent samples were subjected to different concentration of algae that were initially screened for adaptability performed in test tubes. Concentrations used in the present study for effluent treatment are $50 \%, 60 \%, 70 \%$, $80 \%, 90 \%$, and $100 \%$. To attain $50 \%$ concentration $(5.0 \mathrm{ml}$ of effluent sample $+5.0 \mathrm{ml}$ of algae), $60 \%$ concentration $(6.0 \mathrm{ml}$ of effluent sample $+4.0 \mathrm{ml}$ of algae), $70 \%$ (7.0 ml of effluent sample $+3.0 \mathrm{ml}$ of algae), $80 \%$ concentration $(8.0 \mathrm{ml}$ of effluent $+2.0 \mathrm{ml}$ of microalgae), $90 \%$ concentration $(9.0 \mathrm{ml}$ of effluent $+1.0 \mathrm{ml}$ of microalgae) were added.

\section{Evaluation of the growth study}

The algae samples were collected during the treatment process and were analyzed for dry weight at every 4 days interval. $2.0 \mathrm{ml}$ of algal culture was collected and centrifuged at $10,000 \mathrm{rpm}$ for $10 \mathrm{~min}$. The suspension was removed, the pellet was air dried and its weight was noted.

\section{Chlorophyll estimation}

Total chlorophyll estimation of the algae was performed on varying concentration of effluent as well as during the largescale cultivation. For this assay (Hansmann 1973), $5.0 \mathrm{mg}$ dry biomass was suspended in an $8 \%(90 \% \mathrm{v} / \mathrm{v}$ acetone) for extraction. The tube was vortexed, ultrasonicated for $10 \mathrm{~min}$ and incubated for $48 \mathrm{~h}$ at $4{ }^{\circ} \mathrm{C}$. After incubation, the extract was centrifuged at $8000 \mathrm{rpm}$ for $10 \mathrm{~min}$. The supernatant was collected and its absorbance was read in three wavelengths 665, 645 and $630 \mathrm{~nm}$ in Shimadzu UV-Vis spectrophotometer (UV-1800). The amount of chlorophyll present in the algae was calculated by the following equations (Tredici 1999; Molina Grima et al. 1999):

$$
\begin{aligned}
& \mathrm{Ch}_{\mathrm{a}}=11.6 \times \mathrm{OD}_{665}-1.31 \times \mathrm{OD}_{645}-0.14 \times \mathrm{OD}_{630} \\
& \mathrm{Ch}_{\mathrm{b}}=20.7 \times \mathrm{OD}_{645}-4.34 \times \mathrm{OD}_{665}-4.42 \times \mathrm{OD}_{630} \\
& \mathrm{Ch}_{\mathrm{c}}=55.0 \times \mathrm{OD}_{630}-4.64 \times \mathrm{OD}_{665}-16.3 \times \mathrm{OD}_{645},
\end{aligned}
$$

$\left[\mathrm{Ch}_{\mathrm{a}}, \mathrm{Ch}_{\mathrm{b}}\right.$ and $\mathrm{Ch}_{\mathrm{c}}$ represent different types of chlorophyll $(\mathrm{mg} / \mathrm{l})$ and $\mathrm{OD}_{\mathrm{xxx}}$ is the optical density read at specified wavelength] Upon initial screening of two algae for the treatment of effluent samples. The concentration that revealed higher biomass and chlorophyll content was selected for further treatment process. In $1000 \mathrm{ml}$ treatment process, the biomass and chlorophyll content was analyzed in both the effluent samples. 


\section{Optimization of tannery effluent for growth}

The effluent samples collected from two sites were subjected to different effluent concentration $(50 \%, 60 \%, 70 \%, 80 \%$, $90 \%$ and $100 \%$ ). The (setup) treatment was shaken thrice a day to enable complete mixing of the medium with the cultures. The faster algal growth in the effluent will lead to better degradation efficiency of effluent. The growth was visualized with high intensity of green color. Further confirmation can be made using the biomass determination and UV-spectrophotometer readings at $600 \mathrm{~nm}$.

\section{Physiochemical parameters}

The physiochemical parameters such as $\mathrm{pH}$, total suspended solids (TSS), total solids (TS), total dissolved solids (TDS), chloride, sulphate, chromium, total hardness, calcium, magnesium, total alkalinity, iron content, phosphate, biological oxygen demand (BOD), chemical oxygen demand (COD) for the two effluent samples were analyzed both prior and after treatment. The degraded parameters in effluent will be determined after the treatment process (APHA 2005).

\section{Large-scale treatment of effluent sample $(1000 \mathrm{ml})$}

The screening for different concentration of the effluent showed high growth rate at $50 \%$ and this was repeated twice to get standard values. For pilot-scale treatment process, $50 \%$ of the effluent was used that was diluted using BG 11 and BBM broth to make up the volume to $1000 \mathrm{ml}$ (1:1 ratio). During the treatment process, the cells were analyzed for biomass weight at every 4 days interval for a period of 16 days and the chlorophyll content was evaluated.

\section{Biochemical analysis during treatment process}

\section{Protein estimation}

For estimating the protein content in algae, Lowry et al. (1951) was used. Different concentrations of BSA $(1 \mathrm{mg} / \mathrm{ml})$ were prepared with water. The total volume in each test tube was $5.0 \mathrm{ml}$ with standards ranging from 0.05 to $1.0 \mathrm{mg} / \mathrm{ml}$. From these dilutions, $0.2 \mathrm{ml}$ solution was taken and added into different test tubes followed by addition of $2.0 \mathrm{ml}$ alkaline copper sulphate that was mixed gently. This solution was incubated for $10 \mathrm{~min}$ at room temperature in dark condition and $0.2 \mathrm{ml}$ of Folin ciocalteau reagent was added to each tube and incubated for $30 \mathrm{~min}$. The absorbance of standards and unknown samples were read at $660 \mathrm{~nm}$.

\section{Total carbohydrates}

To $100 \mathrm{mg}$ of algal biomass $8.0 \mathrm{ml}$ of perchloric acid ( $20 \% \mathrm{w} / \mathrm{w})$ was added, ultrasonicated to $10 \mathrm{~min}$ and kept for hydrolyzing $(12 \mathrm{~h})$. This hydrolysate was filtered and diluted to $250 \mathrm{ml}$ with distilled water. $5.0 \mathrm{ml}$ of anthrone reagent was added to $1.0 \mathrm{ml}$ of the filtrate, this mixture was boiled to $100{ }^{\circ} \mathrm{C}$ for $10 \mathrm{~min}$. This green-colored solution was cooled by ice bath and its optical density was read at $630 \mathrm{~nm}$. A calibration curve was plotted for each experiment, using D + glucose dissolved in distilled water (Miron et al. 2002). The glucose concentration $(\mathrm{Cg}, \mathrm{mg} / \mathrm{ml})$ and the optical density had the following relationship:

$\mathrm{Cg}=0.536 \times \mathrm{OD}_{630}+0.0028$.

\section{Fluorescence microscopy to detect lipids}

The fluorescence microscopy analysis of the microalgal cells were stained with $5 \mu \mathrm{l}$ of $500 \mu \mathrm{g} / \mathrm{ml}$ of nile red stain (Sigma, USA) (stock). The cells were fixed with 5\% paraformaldehyde and examined at $400 \times$ magnification under Novex, epi-fluorescence microscopy (Yilancioglu et al. 2014).

\section{Statistical analysis}

All the experiments were performed in triplicates and their mean $( \pm)$ standard deviation values were calculated using Microsoft excel 2007. The graphs were plotted using the Graph pad prism v.5.0 software. The standard values were plotted for the estimations performed in this study.

\section{Results}

\section{Morphological observation and molecular identification}

A drop of cyanobacteria and microalgae cultures was placed on a grease free slide and a cover slip was placed on it. This slide was observed under the compound microscope at 400 $\times$ magnification. On microscopic analysis, the organisms were found to be Chlorella sp. and Oscillatoria sp. as per key features (Fig. 1a, b). The genomic DNA isolated from the cyanobacteria was amplified by polymerase chain reaction and the length of the amplified product was $751 \mathrm{bp}$. The gene sequence of the isolated cyanobacteria was submitted to NCBI and the accession no. was found to be MH879820 (Fig. 2). 


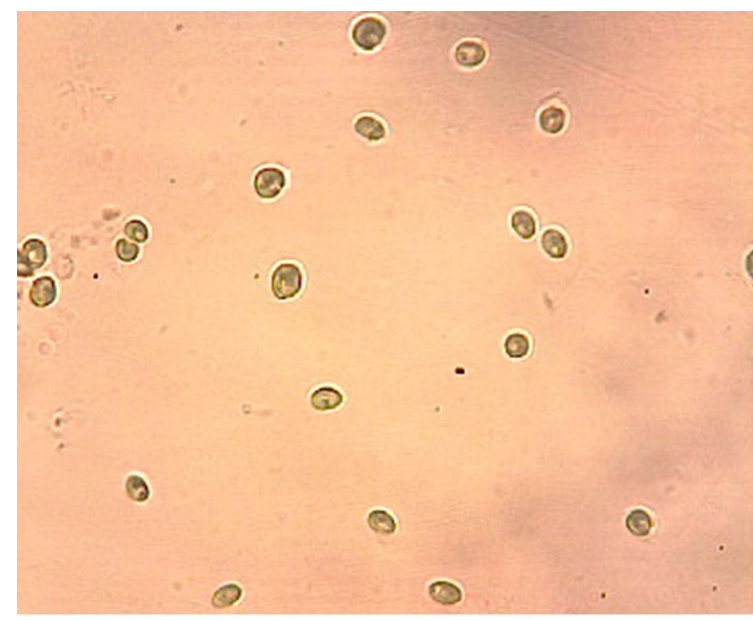

(a)

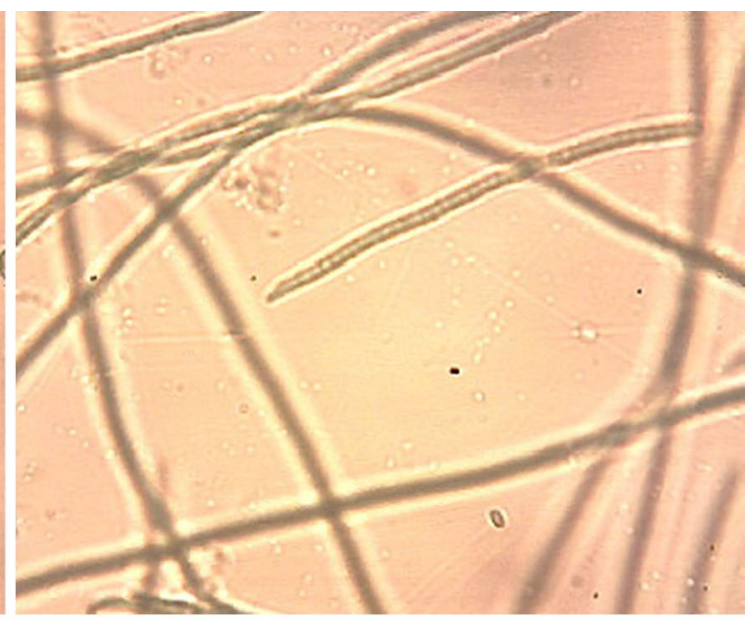

(b)

Fig. 1 Morphological appearance of a Chlorella sp. SRD3 and b Oscillatoria sp. SRD2

\section{Scale up of test isolates culture}

The cyanobacterial and microalgal culture were scaled up to $500 \mathrm{ml}$ of BG11 and BBM in $1000 \mathrm{ml}$ flask, respectively. Cultivated medium was scaled up regularly to provide nourishment to the algal cultures. After 20 days of growth, color change was observed for the intensity of green color (Fig. 3a, b).

\section{Algal growth in effluent collected from BHEL}

The treatment process was performed in $250 \mathrm{ml}$ flasks in six different concentrations for 16 days and its biomass was recorded. The waste water collected from BHEL site was treated with both the algae at different concentrations and it was found that $50 \%$ concentration showed maximum growth in terms of biomass. During treatment, maximum biomass was obtained in Chlorella sp. SRD3 followed by Oscillatoria sp. used for the treatment of effluent sample collected from BHEL the growth was declined as the constituents present in the effluent could not support the growth of this cyanobacteria. The effluent sample treated with Chlorella sp. showed a highest biomass of $0.295 \pm 0.021 \mathrm{~g} / \mathrm{l}$ on 12 th day of treatment as shown in Fig. 4a, b.

\section{Algal growth in effluent collected from Walajapet}

The effluent collected from Walajapet site was treated with both the cyanobacteria and microalgae at different concentrations and a maximum biomass was obtained in 50\% effluent concentration. When Chlorella sp. was used at $50 \%$ concentration it was found that maximum biomass of $0.345 \pm 0.049 \mathrm{~g} / \mathrm{l}$ was present in this concentration, compared to the biomass obtained at other concentrations. The effluent water treated with Oscillatoria sp. showed low biomass at all concentrations proving that this cyanobacterium cannot remediate the effluent (Fig. 5a, b).

\section{Chlorophyll estimation}

The chlorophyll estimation of both the treatment involving effluent collected from BHEL area and Walajapet area with the algal cultures to analyze the growth in the effluent samples. In the BHEL, effluent sample on the 12th and 16th day chlorophyll a and c content was high at 50\% effluent concentration but chlorophyll b was high in $60 \%$ effluent concentration. Whereas in the Walajapet, sample on 12th day the chlorophyll a, b and c content was high in 50\% compared to all other concentrations used, when the same readings were taken on the 16th day chlorophyll a and c content were higher in 50\% concentration but chlorophyll c was higher in $60 \%$ concentration (Fig. 6a, b).

\section{Large-scale treatment of effluent sample with algae (1000 ml)}

The large-scale treatment of the two effluents collected from BHEL and Walajapet area were subjected to continuous aerator for providing $\mathrm{CO}_{2}$ to enhance the growth of algae. Their growth was monitored periodically for 10 days and its biomass yield, chlorophyll and biochemical analysis was performed. An increased biomass and chlorophyll content reveals the adaptability of microalgae and cyanobacteria to tannery effluent. Based on the extent of degradation in the leather effluent treatment process, Chlorella sp. was found to be dominant in growth conditions and chlorophyll yield. Further studies involving large-scale treatment, 


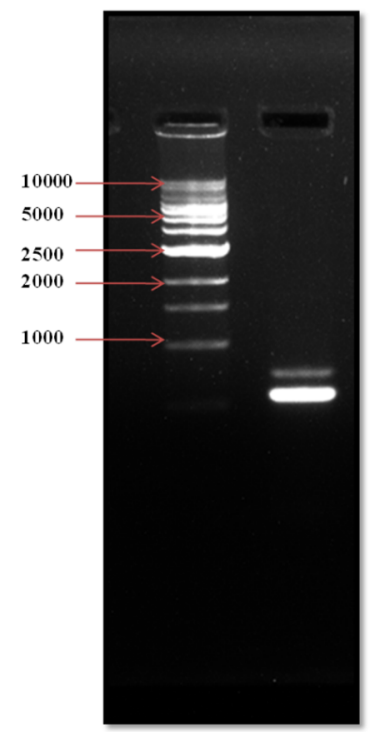

(a)

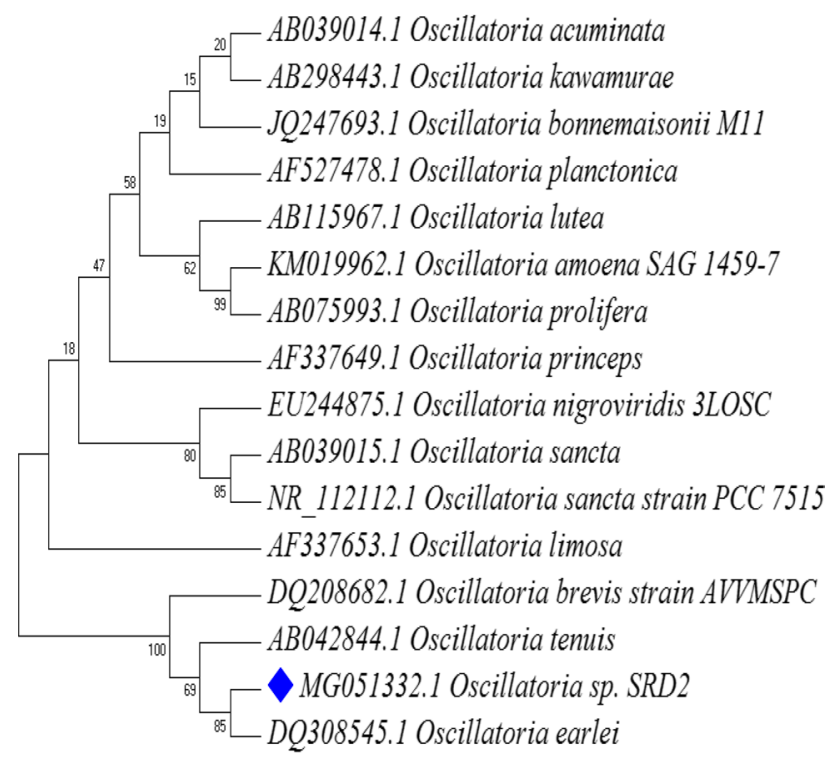

(b)

Fig. 2 a PCR amplified product of Oscillatoria sp. 16 s rRNA gene and $\mathbf{b}$ phylogenetic tree of the Oscillatoria sp.

physiochemical parameters, biochemical analysis will be done with the potent strain Chlorella sp.

\section{Biomass production in large-scale treatment}

The treatment was carried out for a period of 10 days and it was found that in the effluent sample collected from BHEL area the biomass weight was $0.432 \mathrm{~g} / \mathrm{l}$ on 5 th day which gradually increased to $0.65 \pm 0.04 \mathrm{~g} / 1$ on 10 th day. The effluent sample collected from Walajapet area showed an increase in biomass weight from initial 5th day to the 10th day as $0.49 \pm 0.028 \mathrm{~g} / \mathrm{l}$ (Fig. 7).
Fig. 3 Cultivation of algae in broth a Chlorella sp. SRD3 and b Oscillatoria sp. SRD2

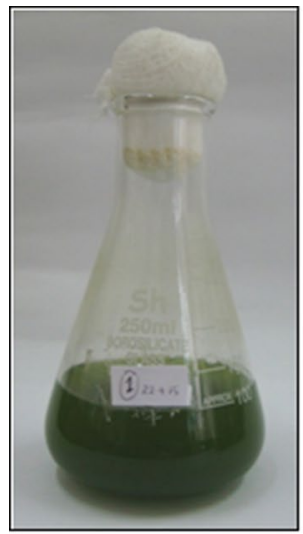

(a)

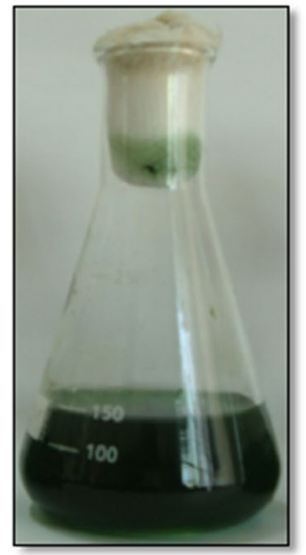

(b)

\section{Chlorophyll estimation of potent isolate}

The Chlorophyll estimation (Chlorophyll a, b and c) of Chlorella sp. obtained from treatment of both the effluent samples showed increased chlorophyll values on 10th day in both the treatment samples. On 5th day, chlorophyll a, b and c content in biomass treated with BHEL effluent showed chlorophyll content ranging from 4.4 to $5.8 \mathrm{mg} / \mathrm{l}$ and that of Walajapet site showed chlorophyll content in rage $3.6-4.3 \mathrm{mg} / \mathrm{l}$. This content gradually increased to $6.2-7 \mathrm{mg} / \mathrm{l}$ and $7.2-8.1 \mathrm{mg} / \mathrm{l}$ in BHEL and Walajapet sites, respectively (Fig. 8a, b).

\section{Physiochemical parameters}

The physiochemical parameters of the effluent collected from two sites were analyzed both before and after treatment. The results showed drastic decrease in some parameters. The effluent collected from the two sites namely BHEL and Walajapet area showed a decline in TDS, total solids, Total suspended solids, total alkalinity, BOD, COD and total hardness levels. The metal concentrations such as chromium, calcium and magnesium values have also decreased, the other elements also have shown decrease in results pertaining to before treatment (Table 1a, b). 


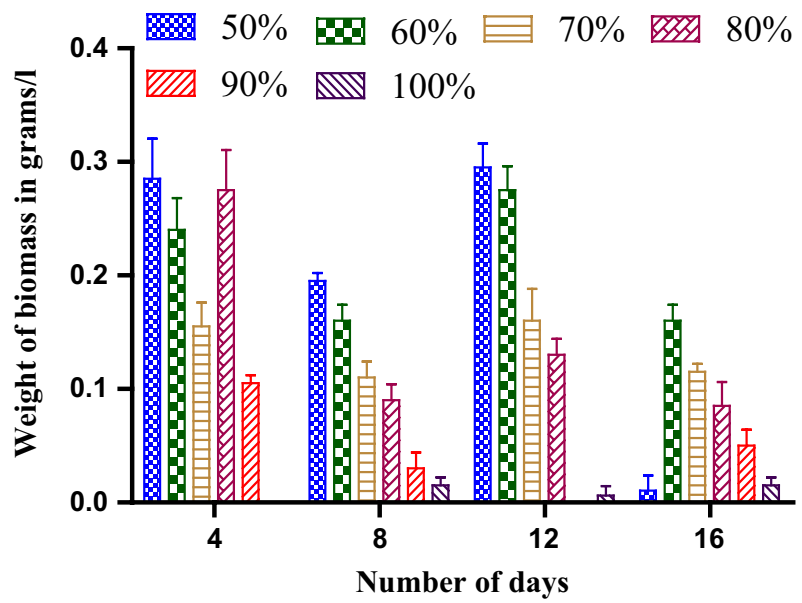

(a)

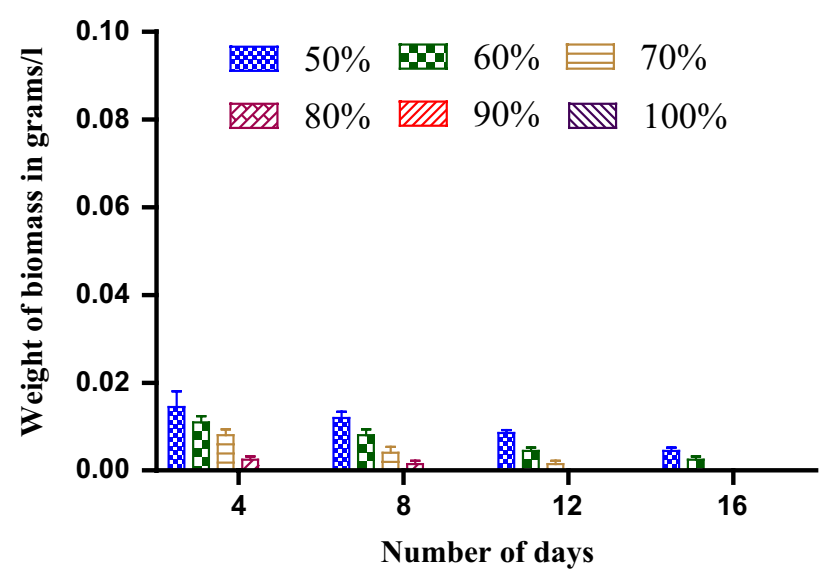

(b)

Fig. 4 Treatment of different effluent concentration of BHEL area using a Chlorella sp. SRD3 and b Oscillatoria sp. SRD2

\section{Protein and carbohydrate content}

The intracellular protein content of the Chlorella sp. SRD3 was determined at varying stages of effluent treatment process. Initially, the protein content was low during the treatment process that kept increasing till the 10th day. On 10th day, the intracellular protein content was maximum in the Chlorella sp. SRD3 that reveals that during the treatment process intracellular proteins were synthesized that enables the degradation of the constituents in tannery effluent. The carbohydrate content also started to raise $410 \mu \mathrm{g} / \mathrm{ml}$ on the 6th day that gradually decreased to $200 \mu \mathrm{g} / \mathrm{ml}$ on 10th day (Fig. 9).

\section{Lipids observed in fluorescent microscope}

The intracellular lipids were observed under epi-fluorescence microscope and the cells with lipid content were visualized

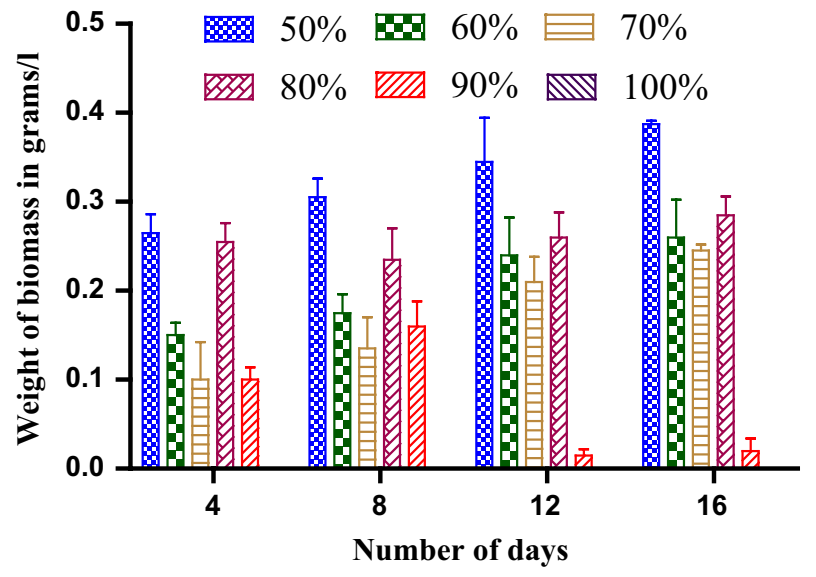

(a)

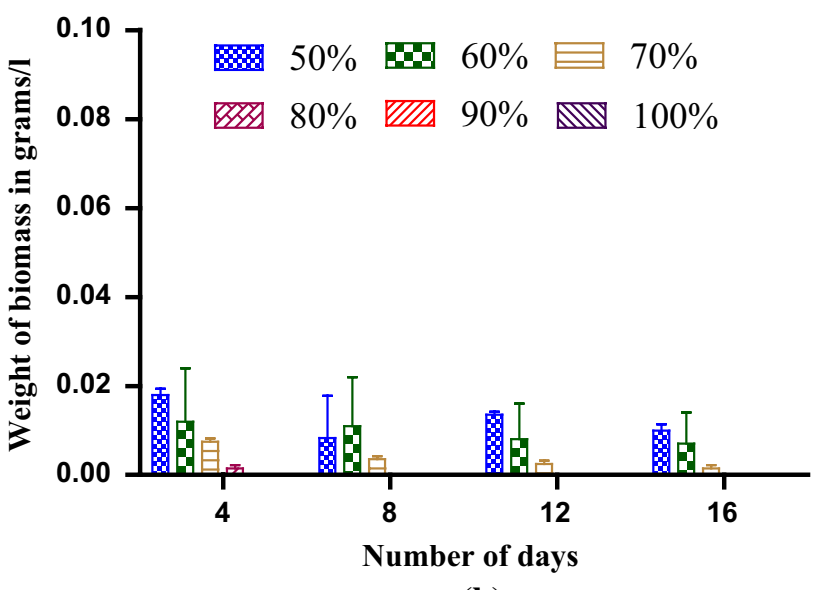

(b)

Fig. 5 Treatment of different tannery effluent concentration from Walajapet by a Chlorella sp. SRD3 and b Oscillatoria sp. SRD2

as yellow-colored cells. This normal view (Fig. 10a) of the microalgal cells when visualized in fluorescence mode showed lipid accumulated bodies (Fig. 10b).

\section{Discussion}

This current study on phycoremediation is on testing the efficacy of microalgae and cyanobacteria involved in reduction of toxic components contained in the collected tannery effluents. Initially, different concentrations of the algal inoculum were treated with tannery effluent to determine the degradation and growth survivability in terms of biomass.

Sharma and Khan (2013) worked on treatment of primarily wastewater treatment by microalgae named Chlorella minutissima, Nostoc sp. and Scenedesmus sp. It was observed that magnificent results were attained by reducing the physiochemical parameters of sewage wastewater by employing the three microalgae. Sengar et al. (2011) in 

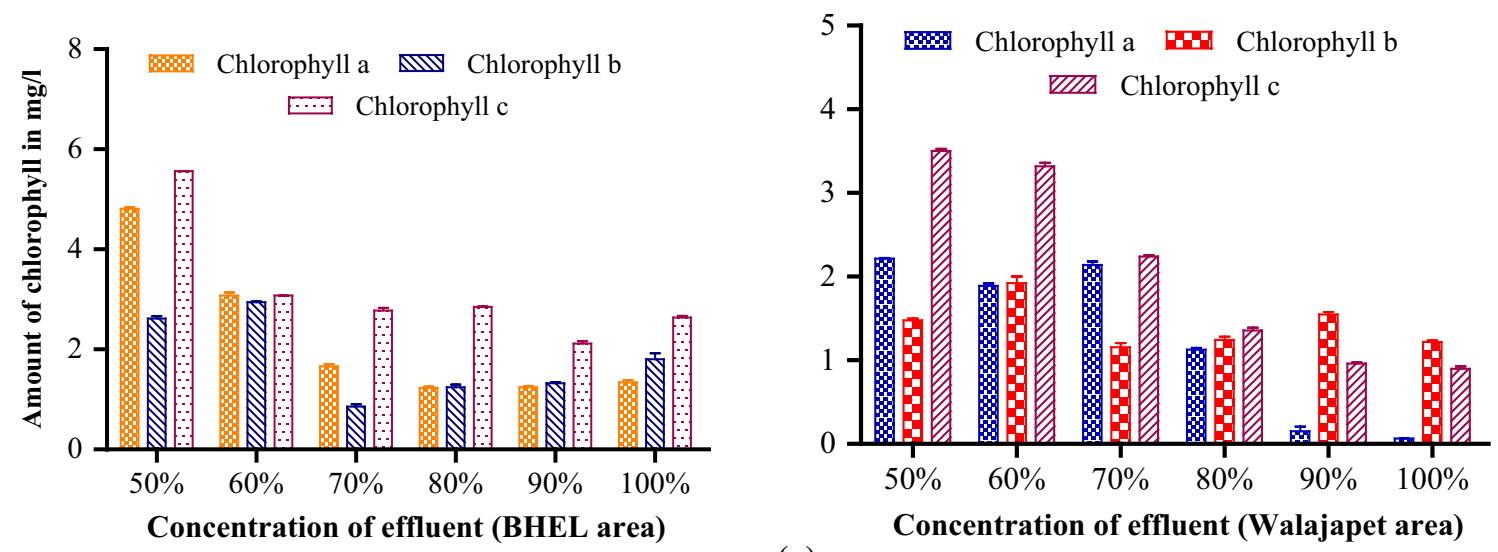

(a)
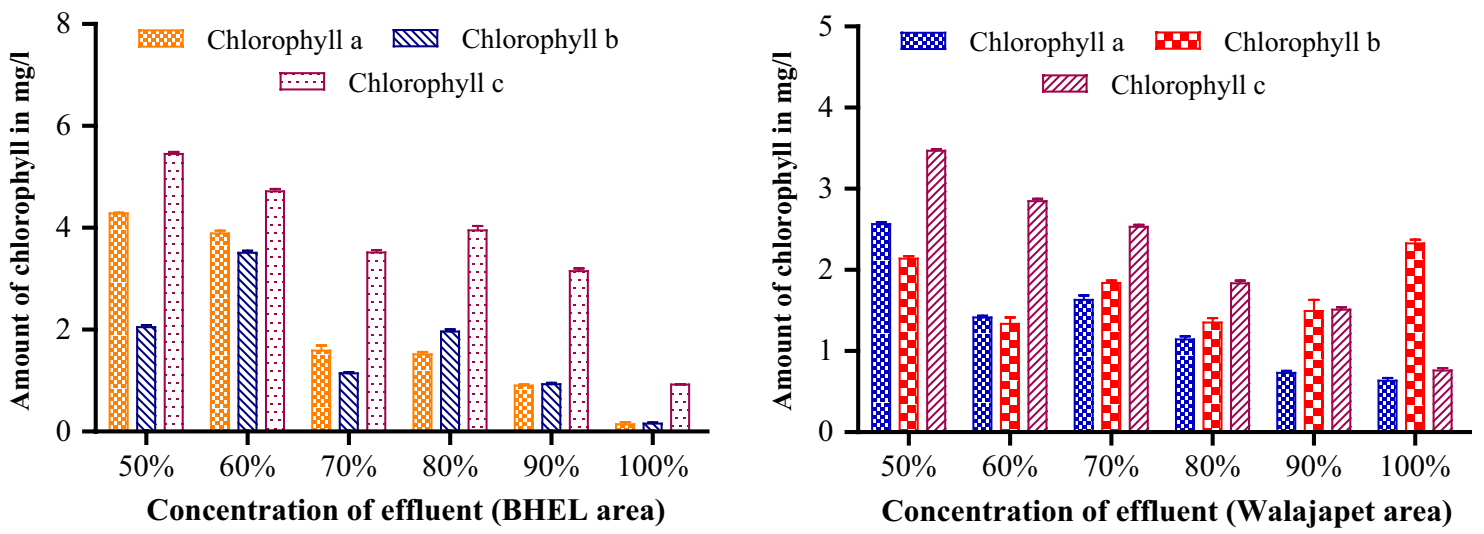

(b)

Fig. 6 Chlorophyll content of biomass treated effluent on a Chlorella sp. SRD3 and b Oscillatoria sp. SRD2

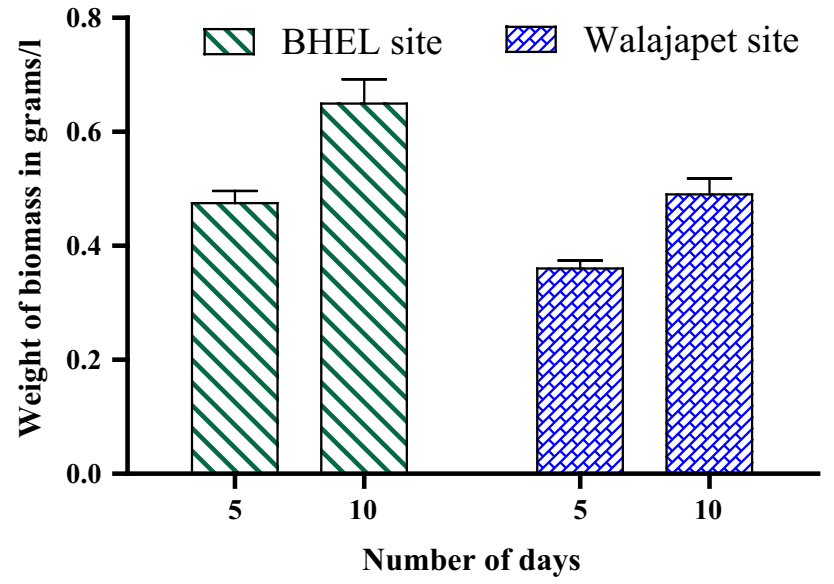

Fig. 7 Biomass of the potent strain during large-scale effluent treatment

his work revealed that algae may hinder by reducing the $\mathrm{pH}$ value of open drain wastewater from 8.1 to 7.1 and increase DO to about $87.5 \%$ on the 25 th day of cultivation. Bioremediation of thermal waste water by Pithosphora sp. showed a better result in removal of physiochemical parameters from 32 to $92 \%$ (Murugesan and Dhamotharan 2009). Based on literature review, it is evident that microalgae are highly potential in degradation and remediation of wastewater. The microalgae Botryococcus sp. had prevailed in the urban wastewater treatment study carried out by Orpez et al. (2009) and in greywater as reported by Gokulan et al. (2013). Gani et al. (2015) employed phycoremediation for treatment of greywater and dairy wastewater using 1000 cells $/ \mathrm{ml}$ as initial inoculum. Their results proved Botryococcus $\mathrm{sp}$. to be effective in the reduction of physicochemical constituents up to $73.3 \%$ of BOD in dairy wastewater thereby removal of $88 \%$ for COD in greywater. The gap in the literature is realized; much more research is needed on Botryococcus sp. upon treatment of wastewater such as domestic and industrial. A major environmental threat to human health is a pollutant that is considered to be a heavy metal (Chekroun et al. 2013). In the present study, also the BOD and COD levels of the effluents was decreased from 76.13 and $83.4 \%$, respectively, in BHEL effluent sample compared to the previous reports using Chlorella sp. SRD3 and Oscillatoria sp. SRD2. The effluent sample collected

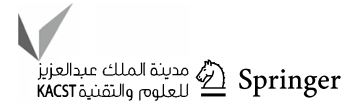




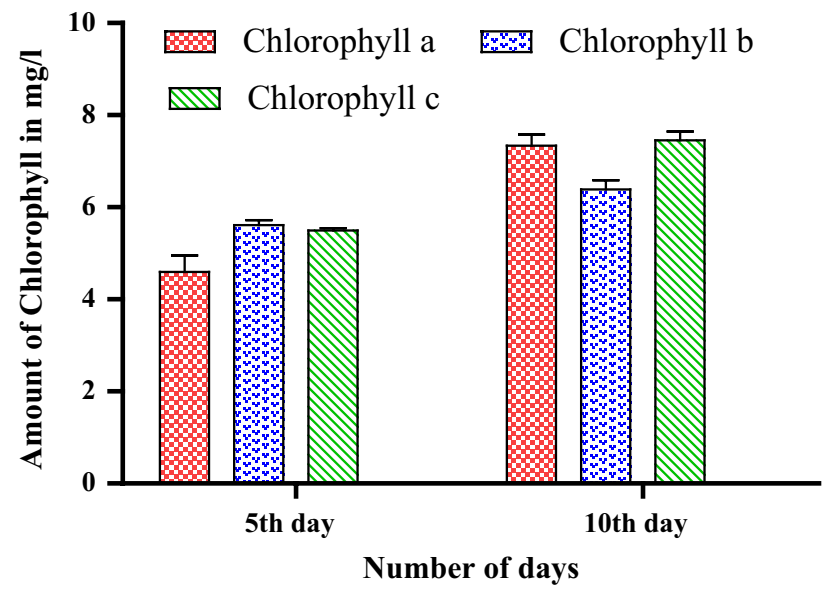

(a)

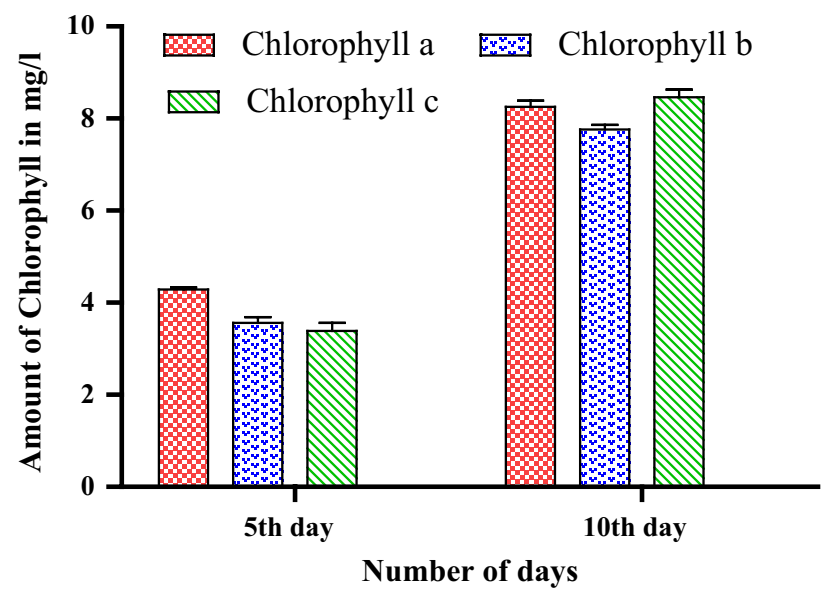

(b)

Fig. 8 Chlorophyll estimation of Chlorella sp. SRD3 treated effluent a BHEL area and $\mathbf{b}$ Walajapet area

from Walajapet site also the BOD and COD levels were found to be reduced to $83.41 \%$ and $76.13 \%$, respectively, in the 10 days treated effluents.

The increased anthropogenic activity is caused due to water bodies getting contaminated by toxic metals and organic pollutants. Therefore phycoremediation is used to assimilate the toxic content present in wastewater. Bioremediation is a process by which specific microbes are transformed to hazardous contaminations in water to nonhazardous waste products (Dwivedi 2012). Dwivedi (2012) proclaimed on surface charge studies showed that availability of free sites depends on $\mathrm{pH}$. As $\mathrm{pH}$ increases the surface charged sites of calcium alginate became more negative, thereby uptaking the metal by increasing the $\mathrm{pH}$. Worku and Sahu (2014) took an effort in culturing Synechocystis salina in groundwater for reduction of heavy metals and total within 15 days treatment. After the treatment, $S$. salina was able to remove $60 \%$ of $\mathrm{Cr}, 66 \%$ of $\mathrm{Fe}, 70 \%$ of $\mathrm{Ni}, 77 \%$ of $\mathrm{Hg}$,
$65 \%$ of $\mathrm{Ca}^{2+}$, and $78 \%$ of total hardness. However, Kumar et al. (2013) had tested the Zinc removal by immobilized and powdered Chlorella marina thereby highest removal of 97\% compared to immobilized with $55.3 \%$ removal. The optimum $\mathrm{pH}$ required for the adsorption of heavy metals by algae is 8 . In phycoremediation of industrial wastewater (Soeprobowati and Hariyati 2013), Porphyridium cruentum isolated from brackish water was employed for assimilating lead, cadmium, copper and chromium. For the above experiment, $\mathrm{pH}(7-8)$, temperature $\left(28-32{ }^{\circ} \mathrm{C}\right)$, salinity (32-34 ppt) and light (4200 1x) were maintained. In our study, also the degradation of metals was observed in Calcium as $82.12 \%$, magnesium $82.51 \%$, iron content $60 \%$ and chromium as $61.90 \%$ from the test sample and control. The same parameters were analyzed for the Walajapet effluent samples and it was found that there was a degradation in the following metals by Oscillatoria sp., as Calcium as $77.22 \%$, magnesium $77.69 \%$, iron content $40 \%$ and chromium as $61.11 \%$ compared to the before treatment analysis.

The wastewater treatment by microalgal bacterial flocs in their study showed significant results in removal of turbidity, BOD, TCOD, TOC, TC, TN and TP are 96\%, 87\%, $80 \%, 71 \%, 48 \%, 58 \%$ and $8 \%$, respectively. Their study also proved the alkaline $\mathrm{pH}$ nature of the final effluent and the DO was $6.06 \mathrm{mg} / \mathrm{l}$ (Van Den Hende et al. 2014). Azarpira et al. (2014) compared two cyanobacterial strains namely Oscillatoria limosa and Nostoc commune for the removal of nutrients using polluted river water. Their results gave average reduction efficiency of between 84 and $98 \%$. In their study, the cynobacteria, Oscillatoria limosa was proven to be better than Nostoc commune. In the present study, microalgae and cyanobacteria namely Oscillatoria sp. and Chlorella $\mathrm{sp}$. were used in the treatment of tannery effluent collected from BHEL and Walajapet area in the vicinity of vellore district. These two effluents were treated with both the cyanobacteria in different concentrations ranging from 50 to $100 \%$ and it was found that in both the sites, only one cyanobacteria was able to grow and produce biomass at higher rates compared to all different concentrations used. The chlorophyll estimation of both the cyanobacteria which showed a better biomass weight were performed and it was found that in both the sites the chlorophyll content was higher in cyanobacteria grown in 50\% concentration of the effluent.

The intracellular protein and carbohydrate was reduced due to nutrient deprivation that led to the higher lipid accumulation in the Chlorella sp., which is observed in nile red staining observed in fluorescent microscope. As per previous reports during stress condition, the protein content tends to decrease thereby increasing the lipid level which is similar to the present study (Pushpakumari Kudahettige et al. 2018). 


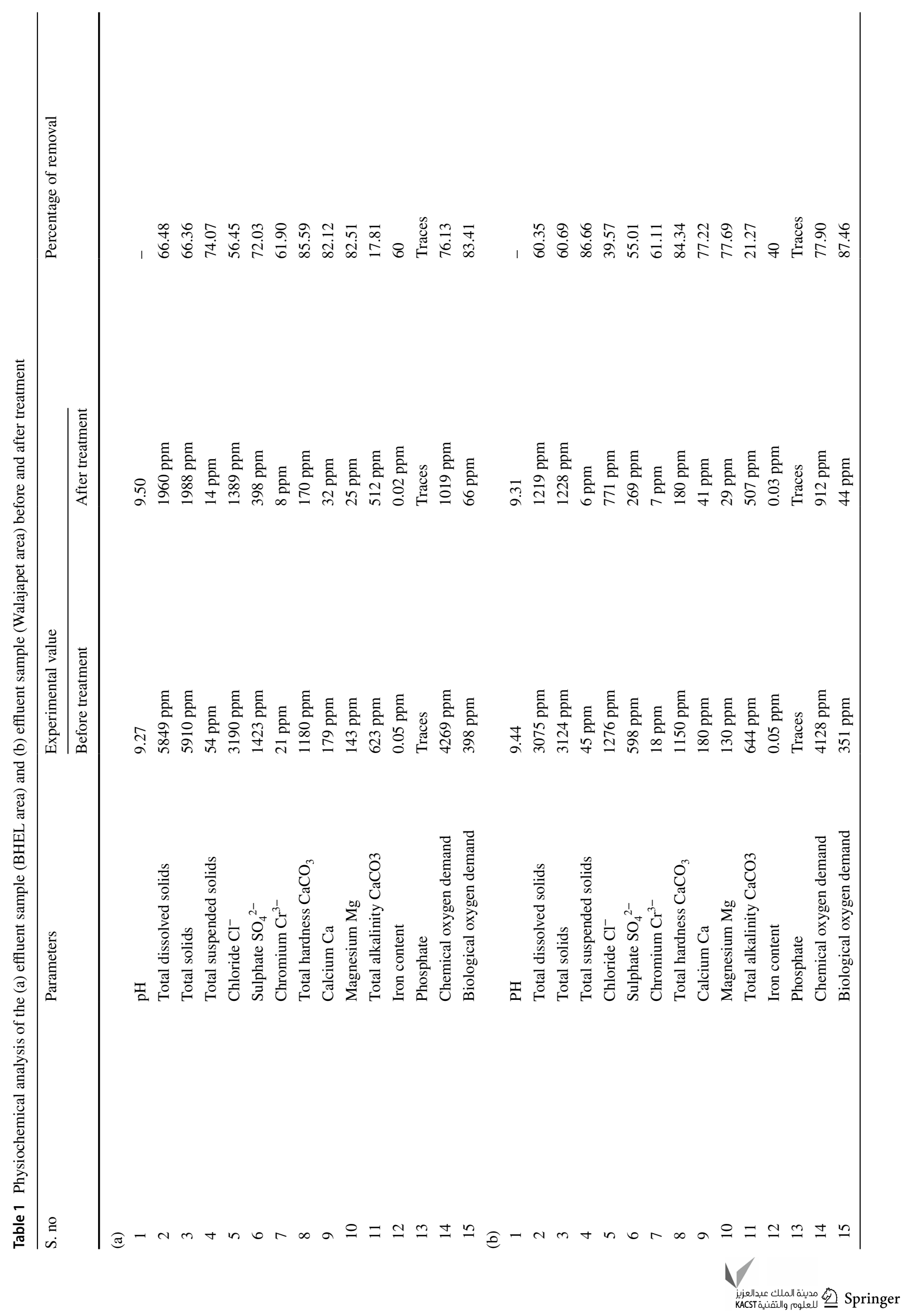




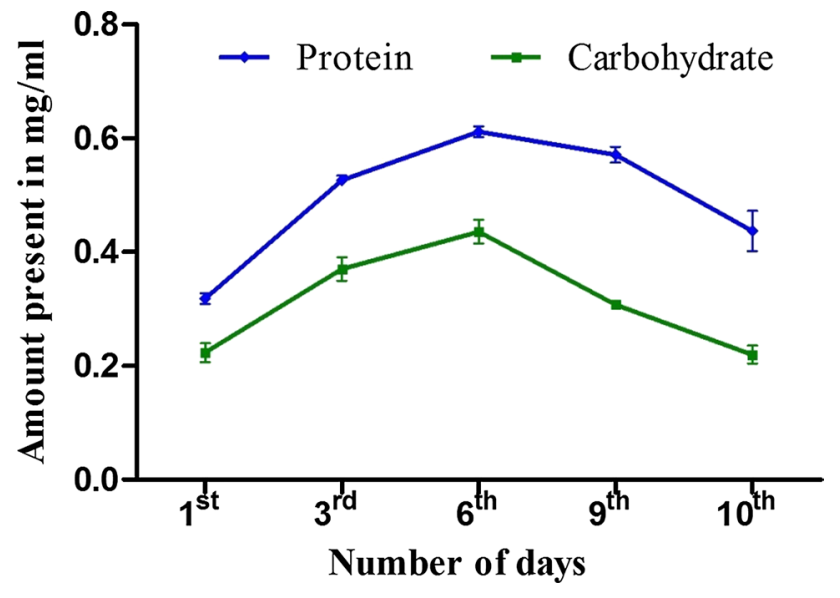

Fig. 9 Changes in the protein and carbohydrate content of Chlorella sp. SRD3 during effluent treatment

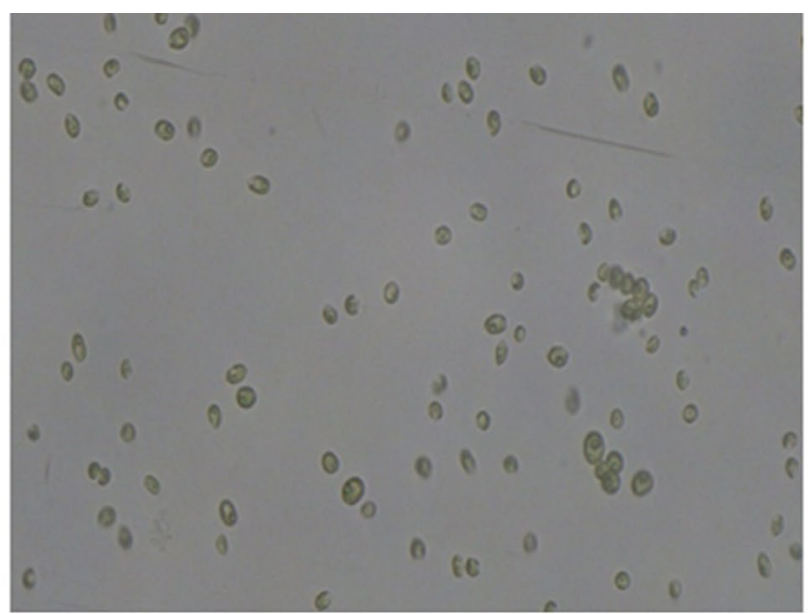

(a)

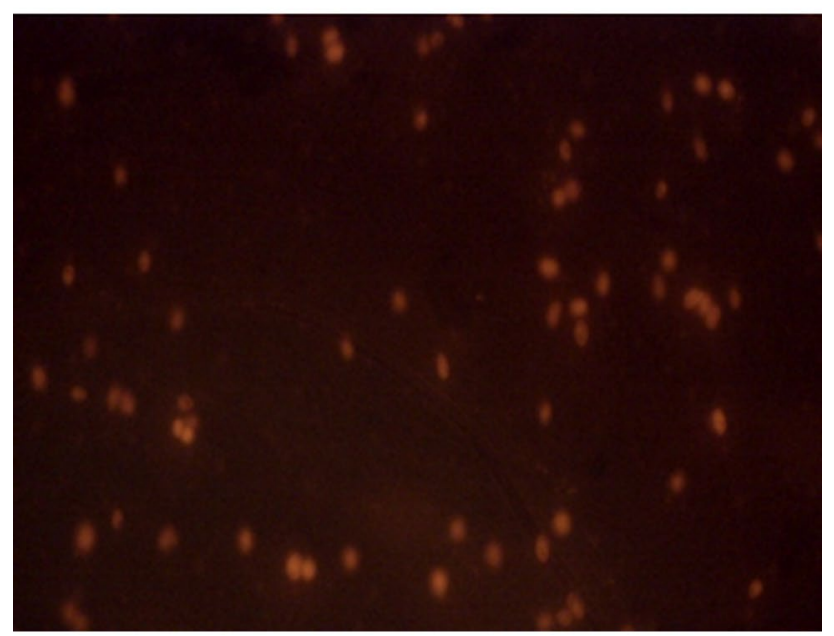

(b)

Fig. 10 Morphological appearance of Chlorella sp. on fluorescent microscope-nile red staining a white light and b UV light

\section{Conclusion}

Tannery effluent waste was initially treated by microalgae and cyanobacteria at $50 \%$ concentration that procures its maximum growth. The chlorophyll was estimated initially as well as during lab scale treatment at larger quantity and physiochemical parameters showed higher reduction rates. As Chlorella sp. was able to degrade the effluents efficiently, it may be employed as a natural source for bioremediation in leather industries before discharging the effluent into environment.

Acknowledgements The authors would like to thank Periyar University for providing sophisticated laboratory facilities to carry out this research work. The authors also sincerely show gratitude to DST-FIST, New Delhi, India for granting sophisticated instrumentation grant with reference No. SR/FST/LSI-640/2015(C) dated 30/5/2016.

\section{Compliance with ethical standards}

Conflict of interest The authors declare that they have no conflicts of interests to disclose.

Ethical approval This article does not contain any studies with human participants or animals, performed by the authors.

Open Access This article is licensed under a Creative Commons Attribution 4.0 International License, which permits use, sharing, adaptation, distribution and reproduction in any medium or format, as long as you give appropriate credit to the original author(s) and the source, provide a link to the Creative Commons licence, and indicate if changes were made. The images or other third party material in this article are included in the article's Creative Commons licence, unless indicated otherwise in a credit line to the material. If material is not included in the article's Creative Commons licence and your intended use is not permitted by statutory regulation or exceeds the permitted use, you will need to obtain permission directly from the copyright holder. To view a copy of this licence, visit http://creativecommons.org/licenses/by/4.0/.

\section{References}

Abdel-Raouf N, Al-Homaidan AA, Ibraheem IB (2012) Microalgae and wastewater treatment. Saudi J Biol Sci 19:257-275

Adefila EO, Onwordi CT, Ogunwande IA (2010) Level of heavy metals uptake on vegetables planted on poultry droppings dumpsite. Arch Appl Sci Res 2:347-353

APHA, AWWA, WEF (2005) Standard methods for the examination of water and wastewater, $21 \mathrm{st}$ edn. National government publication, Washington, D.C. https://www.worldcat.org/title/standard-metho ds-for-the-examination-of-water-and-wastewater/oclc/156744115

Amenorfenyo DK, Huang X, Zhang Y, Zeng Q, Zhang N, Ren J, Huang Q (2019) Microalgae brewery wastewater treatment: potentials, benefits and the challenges. Int J Environ Res Public Health 16:1910

Azarpira H, Behdarvand P, Dhumal K, Pondhe G (2014) Potential use of cyanobacteria species in phycoremediation of municipal wastewater. Int J Biosci 4(4):105-111

Balaji S, Kalaivani T, Sushma B, Pillai CV, Shalini M, Rajasekaran C (2016) Characterization of sorption sites and differential stress 
response of microalgae isolates against tannery effluents from Ranipet industrial area-an application towards phycoremediation. Int J Phytoremediation 18:747-753

Boominathan M, Manoharan C (2008) Interaction of Spirulina platensis with starchy effluent. J Sci Trans Environ Technov 2:102-108

Chekroun KB, Moumen A, Rezzoum N, Sánchez E, Baghour M (2013) Role of macroalgae in biomonitoring of pollution in" Marchica", the Nador lagoon. Phyton (Buenos Aires) 82:31-34

Desikachary TV (1959) Cyanophyta. New Delhi: Indian Council of Agricultural Research

Dhal B, Thatoi HN, Das NN, Pandey BD (2013) Chemical and microbial remediation of hexavalent chromium from contaminated soil and mining/metallurgical solid waste: a review. J Hazard Mater 250:272-291

Dwivedi S (2012) Bioremediation of heavy metal by algae: current and future perspective. J Adv Lab Res Biol 3(3):195-199

Gani P, Sunar NM, Matias-Peralta HM, Latiff A, Aziz A, Joo ITK, Latiff A, Aziz A, Joo IT, Parjo UK, Emparan Q, Er CM (2015) Phycoremediation of dairy wastewater by using green microlgae: Botryococcus sp. Appl Mech Mater 773:1318-1323

Gokulan R, Sathish N, Kumar RP (2013) Treatment of grey water using hydrocarbon producing Botryococcus braunii. Int J Chem Tech Res 5(3):1390-1392

Hansmann E (1973) Pigment analysis. In: Stein JR (ed) Handbook of phycological methods, culture methods and growth measurements. Cambridge University Press, London, pp 359-368

Karthi R, Meenakshi S (2014) Removal of hexavalent chromium ions using polyaniline/silica gel composite. J Water Process Eng $1: 37-45$

Kumar SD, Santhanam P, Jayalakshmi T, Nandakumar R, Ananth S, Devi AS, Prasath BB (2013) Optimization of $\mathrm{pH}$ and retention time on the removal of nutrients and heavy metal (zinc) using immobilized marine microalga Chlorella marina. J Biol Sci 13(5):400-405

Lowry OH, Rosebrough NJ, Farr AL, Randall RJ (1951) Protein measurment with the Folin phenol reagent. J Biol Chem 193:265-275

Murugesan S, Dhamotharan R (2009) Bioremediation of thermal wastewater by Pithophora sp. Curr World Environ 4(1):137-142

Miron AS, Garcia MCC, Camacho FG, Grima EM, Chisti Y (2002) Growth and biochemical characterization of microalgal biomass produced in bubble column and airlift photobioreactors: studies in fed-batch culture. Enzyme Microb Technol 31(7):1015-1023

Molina Grima E, Acién Fernández FG, Garcia Camacho F, Chisti Y (1999) Photobioreactors: light regime, mass transfer, and scaleup. J Biotechnol. 70:231-247

Órpez R, Martínez ME, Hodaifa G, El Yousfi F, Jbari N, Sánchez S (2009) Growth of the microalga Botryococcus braunii in secondarily treated sewage. Desalination 246(1-3):625-630

Pushpakumari Kudahettige N, Pickova J, Gentili FG (2018) Stressing algae for biofuel production: biomass and biochemical composition of Scenedesmus dimorphus and Selenastrum minutum grown in municipal untreated wastewater. Front Energy Res 6:132
Saitou N, Nei M (1987) The neighbor-joining method: a new method for reconstructing phylogenetic trees. Mol Biol Evol 4(4):406-425

Sara AR, Raut N, Fatma AQ, Qasmi M, Al Saadi A (2012) Treatments of industrials wastewater by using microalgae. International Conference on Environmental, Biomedical and Biotechnology. IPCBEE 41:217-221

Sayin S, Yilmaz AB, Ergun N, Turan F (2011) Competitive biosorption of different forms of lead $[\mathrm{Pb}(\mathrm{NO} 3) 2$ and $\mathrm{Pb}(\mathrm{CH} 3 \mathrm{COO}) 2]$ on growth, biomass and proline in Spirulina platensis (Cyanophyta). Afr J Biotechnol 10:18458-18462

Sengar RM, Singh KK, Singh S (2011) Application of phycoremediation technology in the treatment of sewage water to reduce pollution load. Ind J Sci Res 2(4):33-39

Sharma GK, Khan SA (2013) Bioremediation of sewage wastewater using selective algae for manure production. Int J Environ Eng Manag 4(6):573-580

Singh SP, Rastogi RP, Häder DP, Sinha RP (2011) An improved method for genomic DNA extraction from cyanobacteria. World J Microbiol Biotechnol 27(5):1225-1230

Soeprobowati TR, Hariyati R (2013) Bioaccumulation of Pb, Cd, Cu, and $\mathrm{Cr}$ by Porphyridium cruentum (SF Gray) Nägeli. Int J Mar Sci 3(27):212-218

Tredici MR (1999) Bioreactors, photo. In: Flickinger MC, Drew SW (eds) Encyclopedia of bioprocess technology: fermentation, biocatalysis and bioseparation, vol 1. Wiley, New York, pp 395-419

Van Den Hende S, Beelen V, Bore G, Boon N, Vervaeren H (2014) Upscaling aquaculture wastewater treatment by microalgal bacterial flocs: from lab reactors to an outdoor raceway pond. Bioresour Techno 159:342-354

Vijayakumar S, Tajudden N, Manoharan C (2005) Role of cyanobacteria in the treatment of dye industry effluent. Pollut Res 24:79-84

Vijayakumar S, Manoharan C (2012) Treatment of dye industry effluent using free and immobilized cyanobacteria. J Bioremed Biodeg 3(10): $1-6$

Wang L, Li Y, Chen P (2010) Anaerobic digested dairy manure as a nutrient supplement for cultivation of oil-rich green microalgae Chlorella sp. Bioresour Technol 101(8):2623-2628

Worku A, Sahu O (2014) Reduction of heavy metal and hardness from ground water by algae. J Appl Environ Microbiol 2(3):86-89

Yilancioglu K, Cokol M, Pastirmaci I, Erman B, Cetiner S (2014) Oxidative stress is a mediator for increased lipid accumulation in a newly isolated Dunaliella salina strain. PLoS ONE 9(3):e91957

Publisher's Note Springer Nature remains neutral with regard to jurisdictional claims in published maps and institutional affiliations. 